\title{
Investigation of the relationship between drinking water quality based on content of inorganic components and landform classes using fuzzy AHP (case study: south of Firozabad, west of Fars province, Iran)
}

\author{
Marzieh Mokarram ${ }^{1}$ and Dinesh Sathyamoorthy ${ }^{2}$ \\ ${ }^{1}$ Marzieh Mokarram (Department of Range and Watershed Management, College of Agriculture \\ and Natural Resources of Darab, Shiraz University, Iran \\ ${ }^{2}$ Dinesh Sathyamoorthy (Science \& Technology Research Institute for Defence (STRIDE), \\ Ministry of Defence, Malaysia \\ Correspondence to: Marzieh Mokarram (m.mokarram@shirazu.ac.ir)
}

Received: 15 April 2016 - Published in Drink. Water Eng. Sci. Discuss.: 9 June 2016

Revised: 22 September 2016 - Accepted: 5 October 2016 - Published: 28 October 2016

\begin{abstract}
In this study, the fuzzy analytic hierarchy process (AHP) is used to study the relationship between drinking water quality based on content of inorganic components and landform classes in the south of Firozabad, west of Fars province, Iran. For determination of drinking water quality based on content of inorganic components, parameters of calcium $(\mathrm{Ca})$, chlorine $(\mathrm{Cl})$, magnesium $(\mathrm{Mg})$, thorium $(\mathrm{TH})$, sodium $(\mathrm{Na})$, electrical conductivity (EC), sulfate $\left(\mathrm{SO}_{4}\right)$, and total dissolved solids (TDS) were used. It was found that $8.29 \%$ of the study area has low water quality; $64.01 \%$, moderate; $23.33 \%$, high; and $4.38 \%$, very high. Areas with suitable drinking water quality based on content of inorganic components are located in parts of the south-eastern and south-western parts of the study area. The relationship between landform class and drinking water quality based on content of inorganic components shows that drinking water quality based on content of inorganic components is high in the stream, valleys, upland drainages, and local ridge classes, and low in the plain small and midslope classes. In fact we can predict water quality using extraction of landform classes from a digital elevation model (DEM) by the Topographic Position Index (TPI) method, so that streams, valleys, upland drainages, and local ridge classes have more water quality than the other classes. In the study we determined that without measurement of water sample characteristics, we can determine water quality by landform classes.
\end{abstract}

\section{Introduction}

Landform characteristics can affect the direction of water movement and water quality. Hence, in the different landforms, there is different water quality (Bise, 2013). To this end, studies on the relationship between landform classes and water quality have received significant attention. For example, William and Randall (2007) investigated runoff and water quality from three soil landform units on the Mancos Shale. A survey of sediment basins in steep, dissected shale uplands indicated that an average of $1.25 \mathrm{Mg} \mathrm{ha} \mathrm{yr}^{-1}$ of sediment is produced by that landform unit; carefully designed and located basin plugs can be used effectively to trap sediment, water, and salt from dissected shale uplands. Mehdi et al. (2012) determined agricultural land use scenarios for modelling future water quality. The results showed that there is relationship between types of land use and water quality. The impact of land use on water quality was evaluated by Huang et al. (2013). The results indicated that there was significant negative correlation between forest land and grassland and the water pollution, and the built-up area had negative impacts on the water quality, while the influence of the cultivated land on the water quality was very complex. 
Table 1. Descriptive statistics of the parameters for evaluation of water quality (Fars Regional Water Authority).

\begin{tabular}{|c|c|c|c|c|c|}
\hline Parameters & Unit & Minimum & Maximum & Mean & SD \\
\hline Calcium $(\mathrm{Ca})$ & $\mathrm{mg} \mathrm{L}^{-1}$ & 0 & 596 & 195 & 89 \\
\hline Chlorine $(\mathrm{Cl})$ & $\mathrm{mg} \mathrm{L}^{-1}$ & 25 & 437 & 84 & 45 \\
\hline Sodium $(\mathrm{Na})$ & $\mathrm{mg} \mathrm{L}^{-1}$ & 0 & 458 & 51 & 45 \\
\hline Electrical conductivity (EC) & $\mathrm{d} \mathrm{s} \mathrm{m}^{-1}$ & 0.39 & 1.75 & 0.71 & 0.15 \\
\hline Magnesium (Mg) & $\mathrm{mg} \mathrm{L}^{-1}$ & 0 & 569 & 182 & 80 \\
\hline Sulfate $\left(\mathrm{SO}_{4}\right)$ & $\mathrm{mg} \mathrm{L}^{-1}$ & 0 & 584 & 137 & 73 \\
\hline Thorium $(\mathrm{TH})$ & $\mathrm{mg} \mathrm{L}^{-1}$ & 0 & 473 & 180 & 77 \\
\hline Total dissolved solids (TDS) & $\mathrm{mg} \mathrm{L}^{-1}$ & 0 & 954 & 295 & 117 \\
\hline
\end{tabular}

Table 2. Drinking water quality based on content of inorganic component standards (WHO; Shobha et al., 2013).

\begin{tabular}{lc}
\hline Parameters & $\begin{array}{c}\text { Permissible } \\
\text { limit }\left(\mathrm{mg} \mathrm{L}^{-1}\right)\end{array}$ \\
\hline Calcium $(\mathrm{Ca})$ & 200 \\
Chlorine $(\mathrm{Cl})$ & 200 \\
Magnesium $(\mathrm{Mg})$ & 150 \\
Thorium $(\mathrm{TH})$ & 500 \\
Sodium $(\mathrm{Na})$ & 200 \\
Electrical conductivity (EC) & 3000 \\
Sulfate $\left(\mathrm{SO}_{4}\right)$ & 200 \\
Total dissolved solids (TDS) & 500 \\
\hline
\end{tabular}

In addition, different algorithms have been employed for the determination of water quality. Demissie et al. (2012) developed a complementary modelling framework to handle systematic error in physically based groundwater flow model applications that used data-driven models of the errors during the calibration phase. The effectiveness of four error-correcting data-driven models, namely, artificial neural networks (ANN), support vector machines (SVM), decision trees (DT), and instance-based weighting (IBW), was examined for forecasting head prediction errors and subsequently updating the head predictions at existing and proposed observation wells. Rule-based modelling (Manoucher et al., 2010) was used for spatial prediction of groundwater quality in Beaufort West, in the Karoo region of South Africa. The groundwater quality data from about 100 bore wells with a 30-year span collected between 1970 and 2007 were used. The variables used in the analyses included chemicals such as chloride, sulfate, magnesium, sodium, phosphates, and calcium. These were used as predictors for groundwater quality and electrical conductivity. Aliabadi and Soltanifard (2014) used fuzzy inference for determination of the impact of water and soil electrical conductivity and calcium carbonate on wheat crop use. The inference system estimated the performance using soil EC, water EC, and calcium carbonate in the soil as input parameters, and also analysed them.
The aim of this study is the determination of the relationship between landform classes and drinking water quality based on content of inorganic components in southern Firozabad, Iran. In this study, drinking water quality based on content of inorganic components is evaluated using parameters of calcium $(\mathrm{Ca})$, chlorine $(\mathrm{Cl})$, magnesium $(\mathrm{Mg})$, thorium $(\mathrm{TH})$, sodium $(\mathrm{Na})$, electrical conductivity $(\mathrm{EC})$, sulfate $\left(\mathrm{SO}_{4}\right)$, and total dissolved solids (TDS). According to each of the factors for evaluation of water quality with different units (fuzzy method), for preparing the water quality map from factors (AHP) and investigation of spatial (geographic information system - GIS) water quality in the study, it is proposed that the most appropriate method to prepare drinking water quality based on content of inorganic components maps is the fuzzy analytic hierarchy process (AHP method) in a GIS environment. It is expected that the determination of the relationship between landform classes and drinking water quality based on content of inorganic components will allow for the prediction of drinking water quality based on content of inorganic components based on landform classes, so that the study determined that without measurement of water sample characteristics using a DEM and extraction landform classes by the TPI method, we can determine water quality by landform classes.

The methodology employed in this study is summarized in Fig. 1.

\section{Material and method}

\subsection{Case study}

This study was carried out south of Firozabad, west of Fars province, Iran. It has an area of $722.91 \mathrm{~km}^{2}$, and is located between a longitude of $28^{\circ} 36-28^{\circ} 57 \mathrm{~N}$ and a latitude of $52^{\circ} 16-52^{\circ} 46 \mathrm{E}$ (Fig. 2). The altitude of the study area ranges from the lowest of $1134 \mathrm{~m}$ to the highest of $2885 \mathrm{~m}$. The study area is abundantly watered by springs and the perennial Firozabad River. The main agricultural produce consists of grain, fruit, and vegetables, while the partly wooded mountains are used for pasture (Sharifi-Rad et al., 2014). The assessment of land suitability for agricultural production in the 


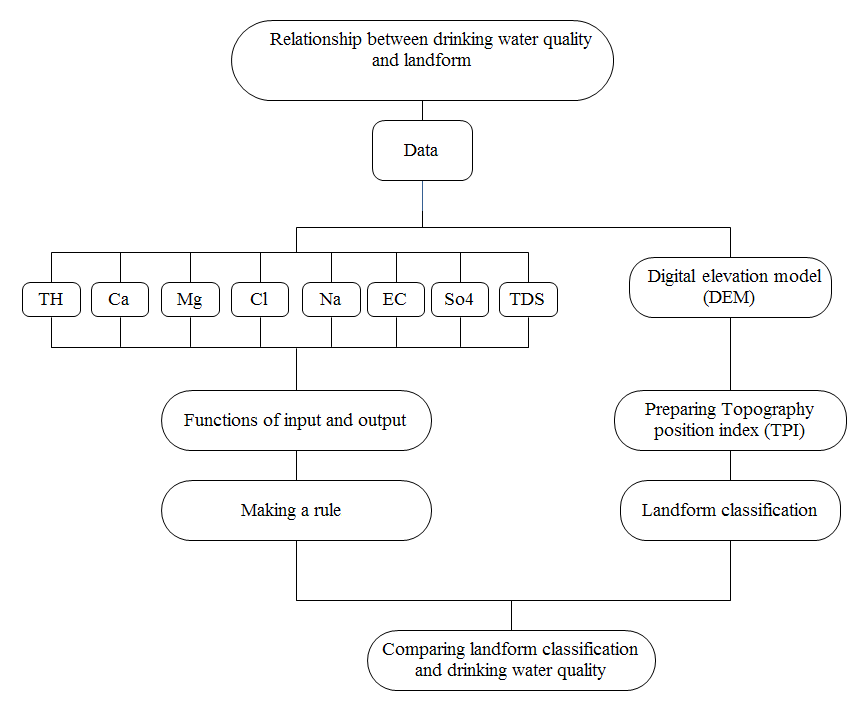

Figure 1. Flowchart for the methodology used in this study to determine the relationship between drinking water quality based on the content of inorganic components and landform classes.

Table 3. Landform classification based on TPI (source: Weiss, 2006).

\begin{tabular}{ll}
\hline Classes & Description \\
\hline Canyons, deeply incised streams & Small neighbourhood: $T_{0} \leq-1$ \\
& Large neighbourhood: $T_{0} \leq-1$ \\
Midslope drainages, shallow valleys & Small neighbourhood: $T_{0} \leq-1$ \\
& Large neighbourhood: $-1<T_{0}<1$ \\
Upland drainages, headwaters & Small neighbourhood: $T_{0} \leq-1$ \\
& Large neighbourhood: $T_{0} \geq 1$ \\
U-shaped valleys & Small neighbourhood: $-1<T_{0}<1$ \\
& Large neighbourhood: $T_{0} \leq-1$ \\
Plains small & Neighbourhood: $-1<T_{0}<1$ \\
& Large neighbourhood: $-1<T_{0}<1$ \\
& Slope $\leq 5^{\circ}$ \\
Open slopes & Small neighbourhood: $-1<T_{0}<1$ \\
& Large neighbourhood: $-1<T_{0}<1$ \\
& Slope $>5^{\circ}$ \\
Upper slopes, mesas & Small neighbourhood: $-1<T_{0}<1$ \\
& Large neighbourhood: $T_{0} \geq 1$ \\
Local ridges/hills in valleys & Small neighbourhood: $T_{0} \geq 1$ \\
& Large neighbourhood: $T_{0} \leq-1$ \\
Midslope ridges, small hills in plains & Small neighbourhood: $T_{0} \geq 1$ \\
& Large neighbourhood: $-1<T_{0}<1$ \\
Mountain tops, high ridges & Small neighbourhood: $T_{0} \geq 1$ \\
& Large neighbourhood: $T_{0} \geq 1$ \\
\hline
\end{tabular}

region is vital, which should consider environmental factors and human conditions.

One of these important factors is drinking water quality based on content of inorganic components in the study area. In order to predict the variability of drinking water quality based on content of inorganic components, calcium $(\mathrm{Ca})$, chlorine $(\mathrm{Cl})$, magnesium $(\mathrm{Mg})$, thorium $(\mathrm{TH})$, sodium $(\mathrm{Na})$, electrical conductivity (EC), sulfate $\left(\mathrm{SO}_{4}\right)$, and total dissolved solids (TDS) were prepared (Table 1; Fars Regional Water Authority).
Table 4. Sampling nugget, partial sill, and RMSE of the different interpolated methods for predicted drinking water quality based on content of inorganic components using multiple linear regression (MLR).

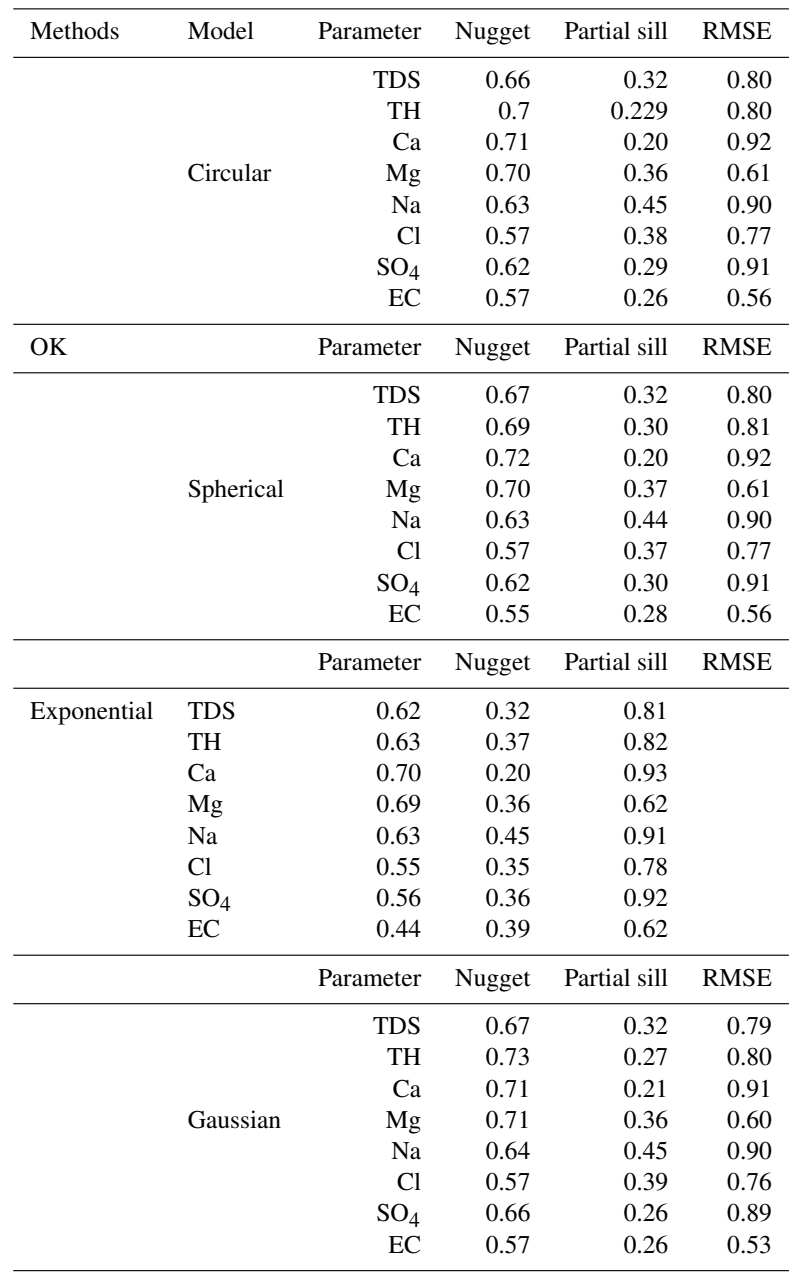

\subsection{Ordinary kriging $(\mathrm{OK})$}

The input parameters for determination of drinking water quality based on content of inorganic components are $\mathrm{Ca}$, $\mathrm{Cl}, \mathrm{Mg}, \mathrm{TH}, \mathrm{Na}, \mathrm{EC}, \mathrm{SO}_{4}$, and TDS. Interpolation maps of these parameters are prepared using ordinary kriging $(\mathrm{OK})$. The presence of a spatial structure where observations close to each other are more alike than those that are far apart (spatial autocorrelation) is a prerequisite for the application of geostatistics (Goovaerts, 1999). The experimental variogram measures the average degree of dissimilarity between unsampled values and a nearby data value, and thus can depict autocorrelation at various distances. The value of the experimental variogram for a separation distance of $h$ (referred to as the lag) is half the average squared difference between the value 


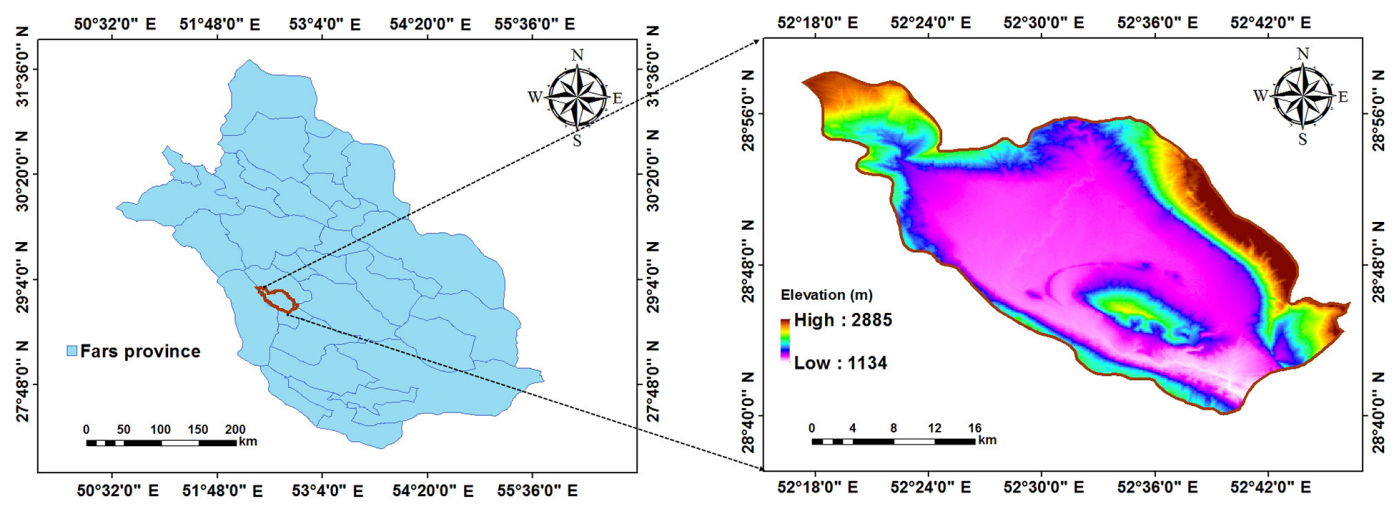

Figure 2. Location of the study area (DEM with a spatial resolution of $30 \mathrm{~m}$; source: http://earthexplorer.usgs.gov).

Table 5. Pair-wise comparison matrix for drinking water quality based on content of inorganic components.

\begin{tabular}{lrrrrrrrrr}
\hline Parameters & $\mathrm{Ca}$ & $\mathrm{Cl}$ & $\mathrm{Na}$ & $\mathrm{EC}$ & $\mathrm{Mg}$ & $\mathrm{SO}_{4}$ & $\mathrm{TH}$ & $\mathrm{TDS}$ & Weight \\
\hline $\mathrm{Ca}$ & 1 & 2 & 3 & 4 & 5 & 6 & 7 & 8 & 0.33 \\
$\mathrm{Cl}$ & 0.5 & 1 & 2 & 3 & 4 & 5 & 6 & 7 & 0.23 \\
$\mathrm{Na}$ & 0.33 & 0.5 & 1 & 2 & 3 & 4 & 5 & 6 & 0.16 \\
$\mathrm{EC}$ & 0.25 & 0.33 & 0.5 & 1 & 2 & 3 & 4 & 5 & 0.11 \\
$\mathrm{Mg}$ & 0.2 & 0.2 & 0.33 & 0.5 & 1 & 2 & 3 & 4 & 0.07 \\
$\mathrm{SO}_{4}$ & 0.16 & 0.16 & 0.2 & 0.33 & 0.5 & 1 & 2 & 3 & 0.05 \\
$\mathrm{TH}$ & 0.14 & 0.14 & 0.16 & 0.2 & 0.33 & 0.5 & 1 & 2 & 0.03 \\
$\mathrm{TDS}$ & 0.12 & 0.12 & 0.14 & 0.16 & 0.2 & 0.33 & 0.5 & 1 & 0.02 \\
\hline
\end{tabular}

at $z\left(x_{i}\right)$ and the value at $z\left(x_{i}+h\right)($ Oliver, 1990):

$\bar{\gamma}(h)=\frac{1}{2 N h} \sum_{i=1}^{N(h)}\left[z\left(x_{i}\right)-z\left(x_{i}+h\right)\right]^{2}$,

where $N$ is the number of pairs of sample points $z\left(x_{i}\right)$ and $z\left(x_{i}+h\right)$ separated by distance $h$ and $\bar{\gamma}(h)$ is the semivariogram. From the analysis of the experimental variogram, a suitable model is then fitted, usually by weighted least squares and four parameters: sill, range, nugget, and anisotropy. Sill refers to the variance value at which the curve reaches the plateau sill. The total separation distance from the lowest variance to the sill is known as the range. Semivariogram modelling is a key step between spatial description and spatial prediction. The main application of kriging is the prediction of attribute values at unsampled locations. There are several models for semivariogram graphs. Figure 3 shows the general shapes and equations of the mathematical models used to describe the semivariance (McBratney and Webster, 1986).

In order to compare the different interpolation techniques, we examined the difference between known and predicted data using the root mean squared error (RMSE; Eq. 2):

$\operatorname{RMSE}=\sqrt{\frac{1}{N} \sum_{i=1}^{N}\left\{z\left(x_{i}\right)-\hat{z}\left(x_{i}\right)\right\}^{2}}$, where $\hat{z}\left(x_{i}\right)$ is the predicted value, $z\left(x_{i}\right)$ is the observed (known) value, and $N$ is the number of values in the dataset (Johnston et al., 2001).

\subsection{Fuzzy AHP}

\subsubsection{Fuzzy classification}

Fuzzy logic was initially developed by Zadeh (1965) as a generalization of classic logic. He defined a fuzzy set by membership functions from properties of objects. A membership function assigns to each object a grade ranging between 0 and 1 . The value 0 means that $x$ is not a member of the fuzzy set, while the value 1 means that $x$ is a full member of the fuzzy set. Traditionally, thematic maps represent discrete attributes based on Boolean memberships, such as polygons, lines, and points. Mathematically, a fuzzy set can be defined as follows (Mc Bratney and Odeh, 1997):

$A=\left\{x, \mu_{A}(x)\right\}$ for each $x \varepsilon X$,

where $\mu_{A}$ is the membership function (MF) that defines the grade of membership of $x$ in fuzzy set $A$. MF takes values between and including 1 and 0 for all $A$, with $\mu_{A}=0$ meaning that $x$ does not belong to $A$ and $\mu_{A}=1$ meaning that it belongs completely to $A$. Alternatively, $0<\mu_{A}(x)$ $<1$ implies that $x$ belongs to a certain degree to $A$. If $X=$ $\left\{x_{1}, x_{2}, \ldots, x_{n}\right\}$, the previous equation can be written as fol- 


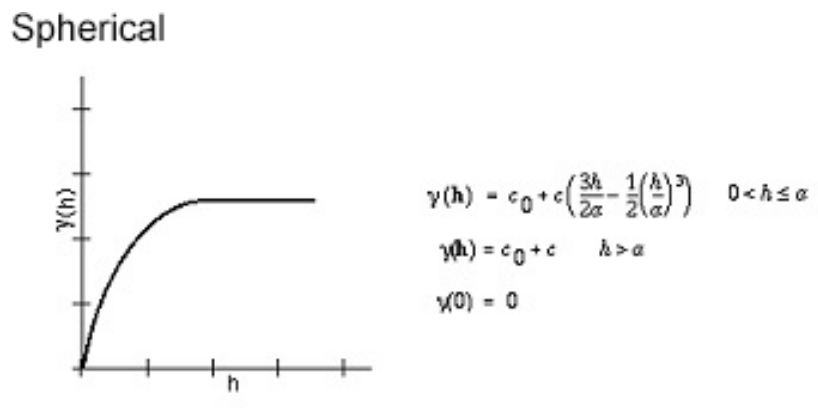

(a)

\section{Circular}

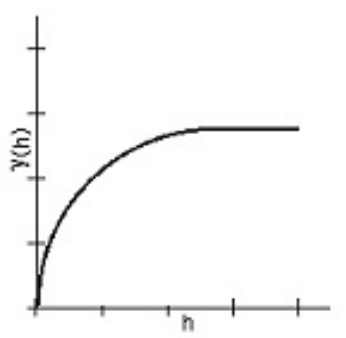

(b)

\section{Exponential}

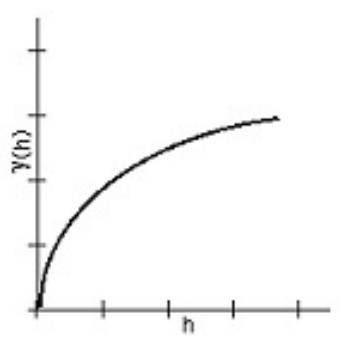

$\gamma(h)=c_{0}+c\left(1-\frac{2}{\pi} \cos ^{-1}\left(\frac{h}{\alpha}\right)+\sqrt{1-\frac{h^{2}}{\sigma^{2}}}\right)$

Wh) $=c_{0}+c \quad h>a$

$x(0)=0$

$$
\begin{aligned}
y(\mathbf{h}) & =c_{0}+c\left(1-\exp \left(\frac{-h}{r}\right)\right) \quad h>0 \\
y(0) & =0
\end{aligned}
$$

(c)

\section{Gaussian}

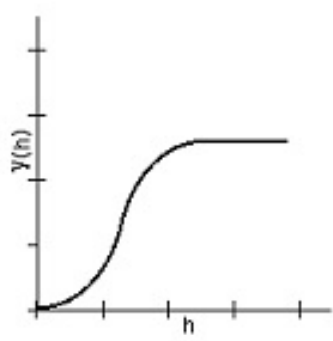

(d)

Figure 3. Semivariogram graphs: (a) spherical; (b) circular; (c) exponential; (d) Gaussian.

$$
\begin{aligned}
& y(h)=c_{0}+c\left(1-\exp \left(-\frac{h^{2}}{r^{2}}\right)\right) \quad h>0 \\
& x(0)=0
\end{aligned}
$$

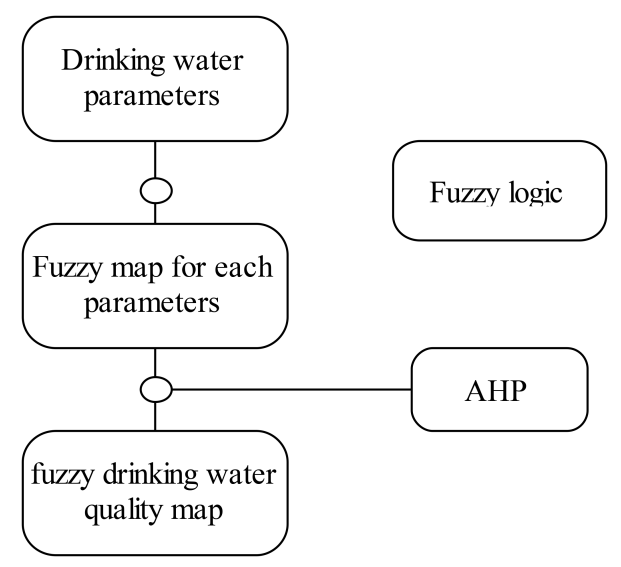

Figure 4. Fuzzy AHP procedure for drinking water quality based on content of inorganic components.

lowing (McBratney and Odeh, 1997):

$A=\left\{\left[x_{1}, \mu_{A}\left(x_{1}\right)\right]+\left[x_{2}, \mu_{A}\left(x_{2}\right)\right]+\ldots . .+\left[x_{n}, \mu_{A}\left(x_{n}\right)\right]\right\}$.

In simple terms, Eqs. (3) and (4) mean that for every $x$ that belongs to the set $X$, there is a membership function that describes the degree of ownership of $x$ in $A$.

The development of GIS has contributed to facilitating the mapping of drinking water quality based on content of inorganic components using both Boolean and fuzzy methods. For each of the parameters, the following function was used (Shobha et al., 2013):

$\mu_{A}(X)=f(x)=\left\{\begin{array}{l}1 \quad x \leq a \\ b-x / b-a \\ 0 \quad x \geq b\end{array} \quad a \prec x \prec b\right\}$.

In order to define the fuzzy rules, the drinking water quality based on the content of inorganic component standards in Table 2 was used.

\subsubsection{Analytic hierarchy process (AHP)}

AHP is a structured technique for organizing and analysing complex decisions. This method is based on a pair-wise comparison matrix. The matrix is called consistent if the transitivity (Eq. 5) and reciprocity (Eq. 7) rules are respected:

$$
\begin{aligned}
& a_{i j}=a_{i k} \times a_{k j}, \\
& a_{i j}=1 / a_{j i},
\end{aligned}
$$

where $i, j$, and $k$ are any alternatives of the matrix.

In a consistent matrix (Eq. 7), all the comparisons $a_{i j}$ obey the equality $a_{i j}=p_{i} / p_{j}$, where $p_{i}$ is the priority of the alternative $i$. When the matrix contains inconsistencies, two 


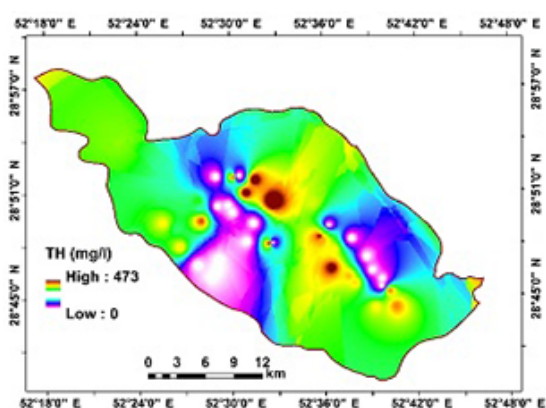

$\mathrm{TH}$

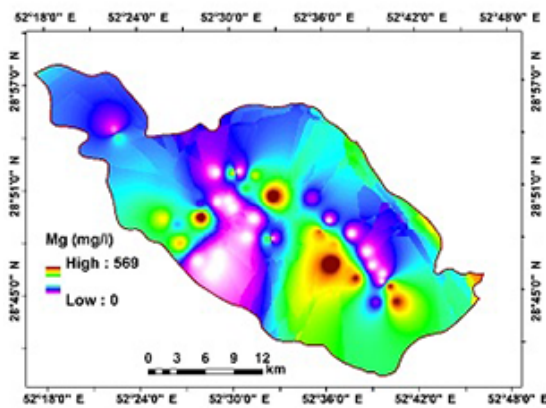

$\mathrm{Mg}$

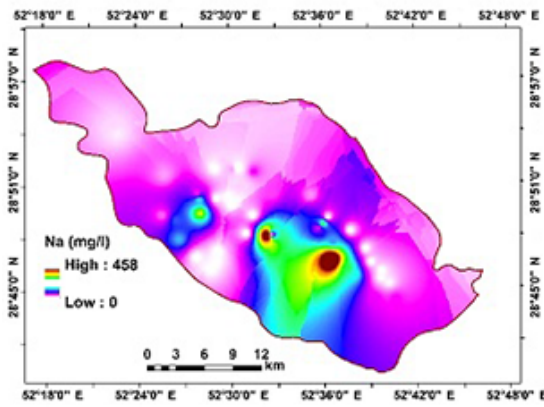

$\mathrm{Na}$

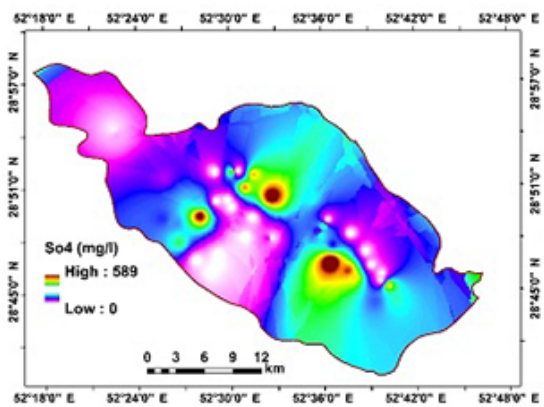

$\mathrm{S}_{4}$

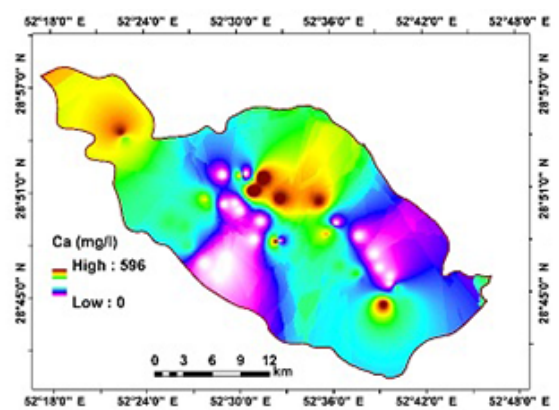

$\mathrm{Ca}$

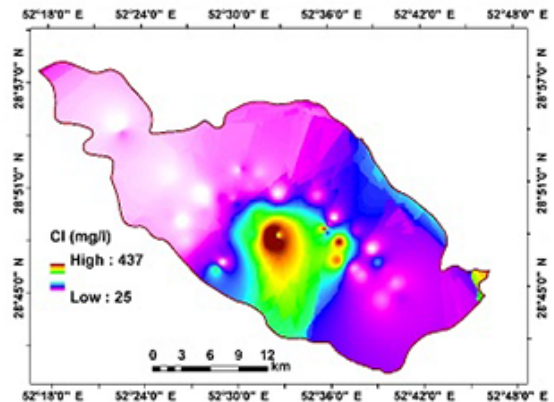

$\mathrm{Cl}$

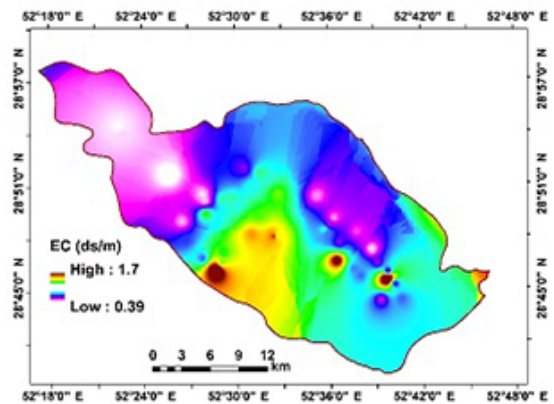

EC

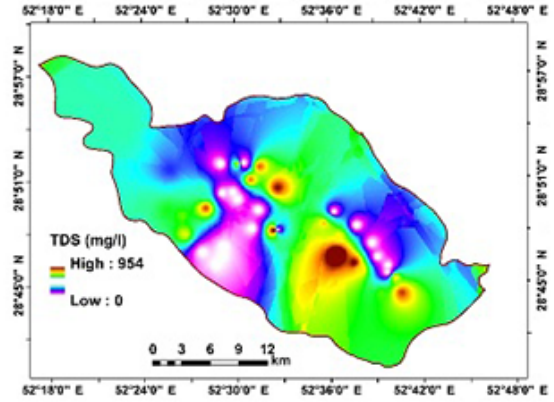

TDS

Figure 5. Interpolated maps of the drinking water quality based on the content of inorganic component parameters generated by using OK. 


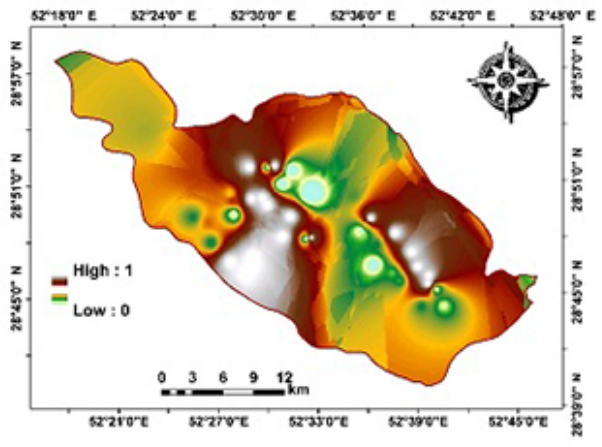

$\mathrm{TH}$

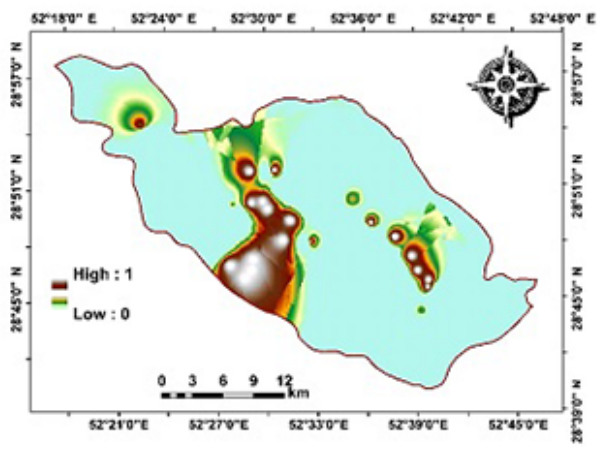

$\mathrm{Mg}$
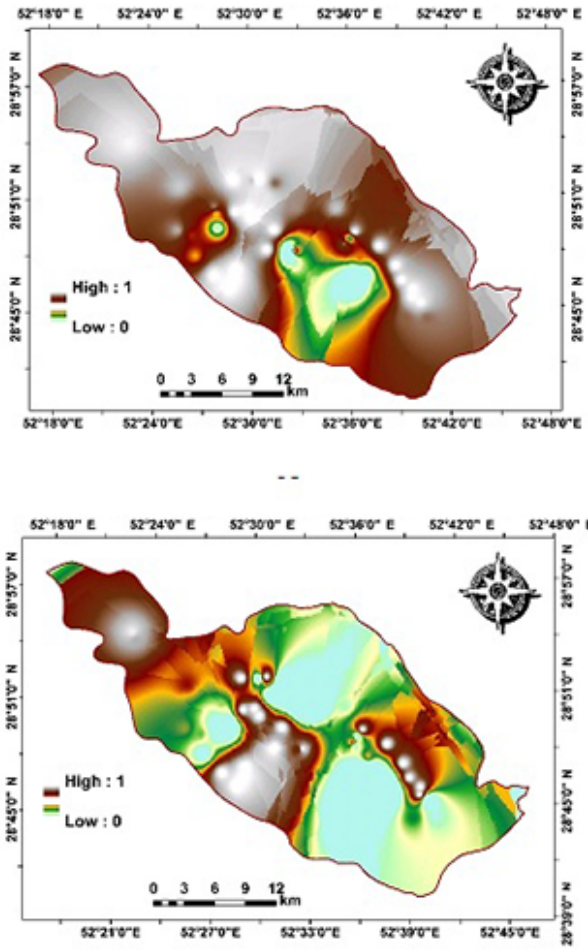

$\mathrm{SO}_{4}$

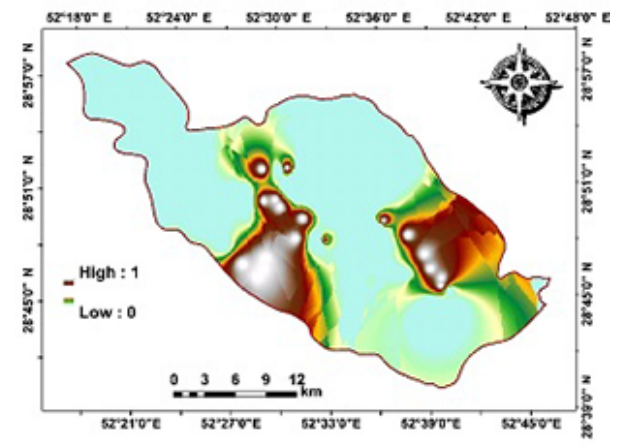

$\mathrm{Ca}$

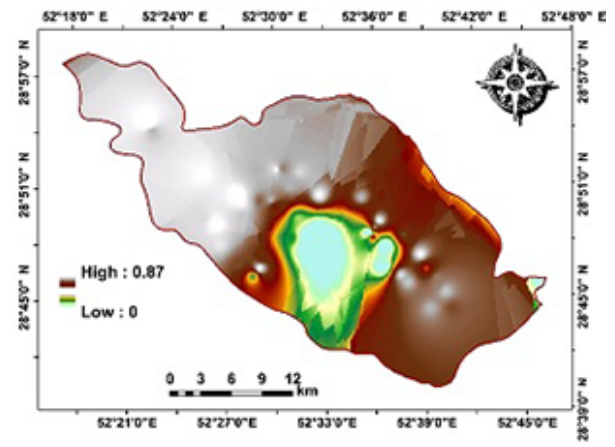

$\mathrm{Cl}$
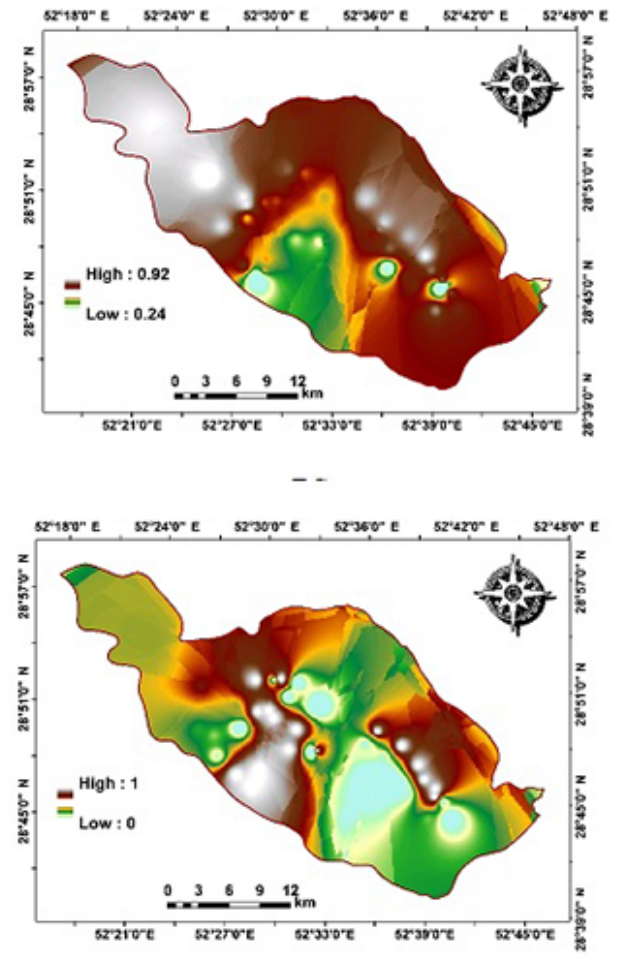

TDS

Figure 6. Fuzzy maps of the study area for the drinking water quality based on the content of inorganic component parameters. 


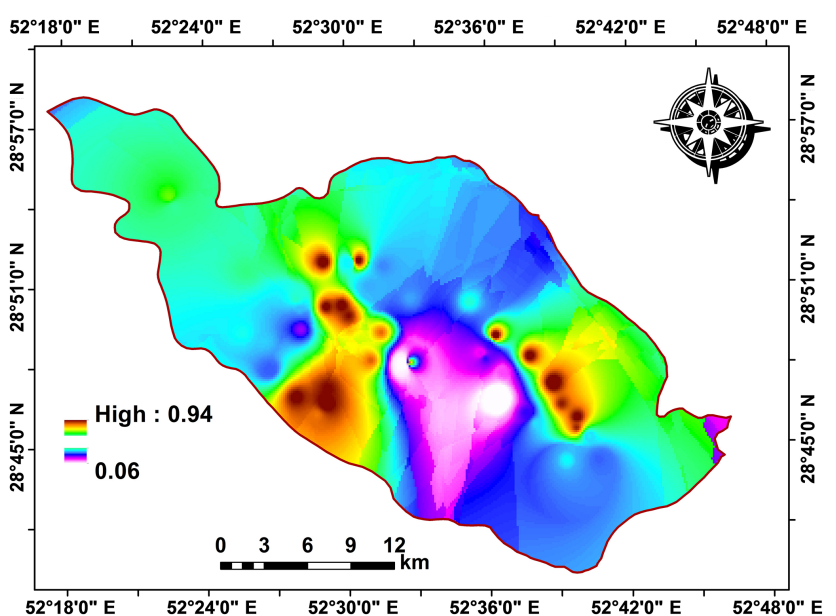

Figure 7. Drinking water quality based on the content of inorganic components map generated using fuzzy AHP.

approaches can be applied:

$$
\left|\begin{array}{ccccc}
P_{1} / P_{1} & \ldots & P_{1} / P_{j} & \ldots & P_{1} / P_{n} \\
\ldots & 1 & \ldots & \ldots & \ldots \\
P_{i} / P_{1} & \ldots & 1 & \ldots & P_{i} / P_{n} \\
\ldots & \ldots & \ldots & 1 & \ldots \\
P_{n} / P_{1} & \ldots & P_{n} / P_{j} & \ldots & P_{n} / P_{n}
\end{array}\right|
$$

In this method, pair-wise comparisons are considered as input, while relative weights are considered as outputs. The average of each row of the pair-wise comparison matrix is calculated and these average values indicate relative weights of compared criteria.

\subsubsection{Combination of fuzzy and AHP methods}

Finally, in order to prepare the drinking water quality based on content of the inorganic components map, it is necessary to calculate the convex combination of the raster values containing the different fuzzy parameters (Bijanzadeh and Mokarram, 2013; Mahdavi et al., 2015). $A_{1}, \ldots A_{k}$ are fuzzy subclasses of the defined universe of objects $X$, and $W_{1}, \ldots W_{k}$ are non-negative weights summing up to unity. The convex combination of $A_{1}, \ldots A_{k}$ is a fuzzy class $A$ (Burrough, 1989), and the weights $W_{1}, \ldots W_{k}$ are calculated using AHP and fuzzy method parameters that have been calculated in ArcGIS. Equations 9 and 10 show the convex combination.

$$
\begin{aligned}
\mu_{A} & =\sum_{j=1}^{k} W_{j} \times \mu_{A(x)} x \varepsilon X \\
\sum_{j=1}^{k} W_{j} & =1 W_{j}>0
\end{aligned}
$$

The fuzzy AHP approach in this study has been divided into five stages, which are summarized in Fig. 4.
Table 6. Areas of the drinking water classes.

\begin{tabular}{lrr}
\hline & \multicolumn{2}{c}{ Area } \\
\cline { 2 - 3 } Class & $(\%)$ & $\left(\mathrm{km}^{2}\right)$ \\
\hline Low & 8.29 & 59.90 \\
Moderate & 64.01 & 462.72 \\
High & 23.33 & 168.65 \\
Very high & 4.38 & 31.64 \\
\hline
\end{tabular}

All the model parameter maps are constructed by interpolation between 50 sampling points using the kriging method. Next, fuzzy logic is applied to create a fuzzy parameter map for each parameter. To arrive at an integrated evaluation using drinking water quality based on content of inorganic component classes, the fuzzy parameter maps were aggregated into a drinking water quality based on content of an inorganic component map following a weighted summation using AHP.

\subsection{Landform classification using the Topographic Position Index (TPI)}

TPI (Weiss, 2006) compares the elevation of each cell in a digital elevation model (DEM) to the mean elevation of a specified neighbourhood around that cell. Positive and negative TPI values represent locations that are higher and lower than the average of their surroundings respectively. TPI values near zero are either flat areas (where the slope is near zero) or areas of constant slope (where the slope of the point is significantly greater than zero; Weiss, 2006).

TPI (Eq. 8) compares the elevation of each cell in a DEM to the mean elevation of a specified neighbourhood around that cell. Mean elevation is subtracted from the elevation value at the centre (Weiss, 2006):

$\mathrm{TPI}_{i}=T_{0}-\sum_{n-1} T_{n} / n$,

where $T_{0}$ is the elevation of the model point under evaluation, $T_{n}$ is the elevation of the grid, and $n=$ is the total number of surrounding points employed in the evaluation.

Combining TPI at small and large scales allows a variety of nested landforms to be distinguished (Table 3).

\section{Results and discussion}

\subsection{Geostatistical analysis}

OK was used for the prediction of the drinking water quality based on content of inorganic component parameters (TH, $\mathrm{Ca}, \mathrm{Mg}, \mathrm{Cl}, \mathrm{Na}, \mathrm{EC}, \mathrm{SO}_{4}$, and TDS). In OK, in order to select the best method (circular, spherical, exponential, or Gaussian), measured nugget, partial sill, and RMSE were used (Table 4). The RMSE of water parameters from Table 


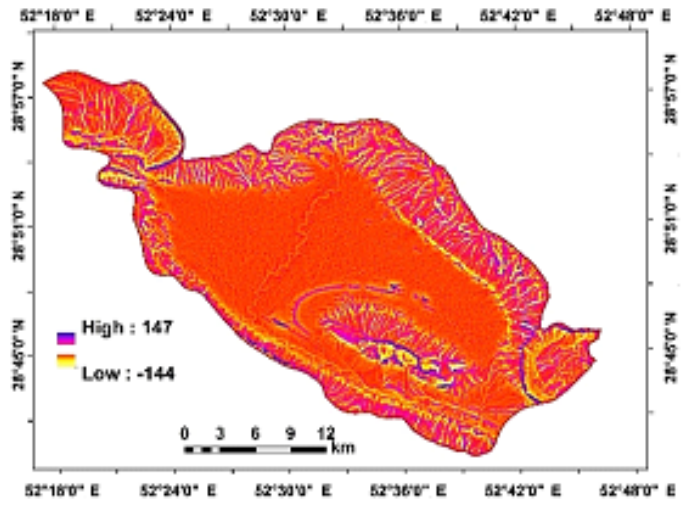

(a)

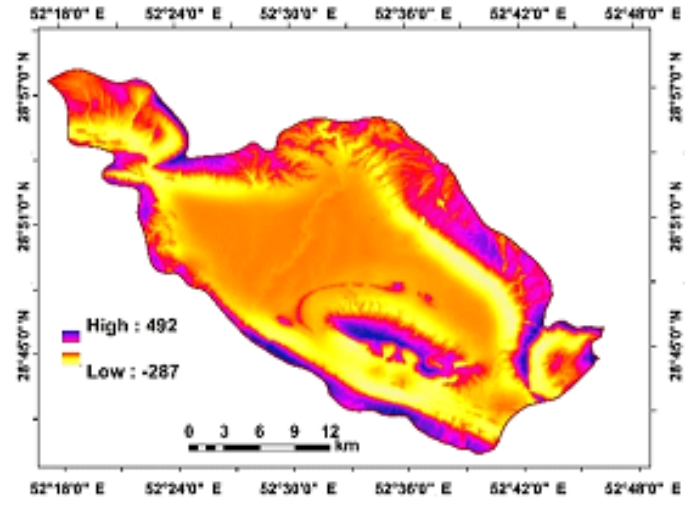

(b)

Figure 8. TPI maps generated using (a) small (3 cells) and (b) large (45 cells) neighbourhoods
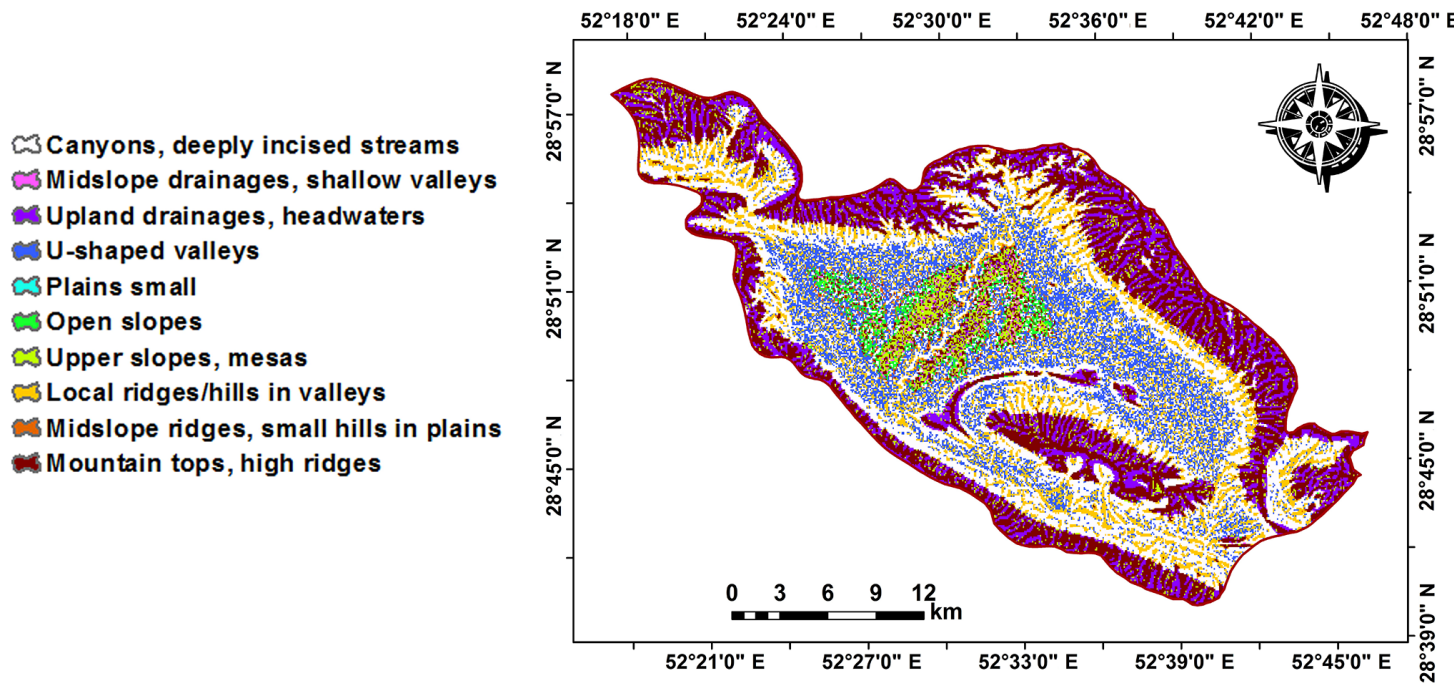

Figure 9. Landform classification using the TPI method.

4 shows that the lowest RMSE is the Gaussian method. Furthermore, these results indicate that the Gaussian model for OK is the best semivariogram model to show the strong spatial dependency for the water variable.

Each of the water parameter maps that were predicted by OK are shown in Fig. 5. The lowest $\mathrm{SO}_{4}$, TDS, $\mathrm{Na}, \mathrm{Mg}$, TH, and $\mathrm{Ca}$ were 0 , while the highest values for the parameters were $589,954,458,569,473$, and $569 \mathrm{mg} \mathrm{L}^{-}$respectively. The lowest values for EC and $\mathrm{Cl}$ were 0.39 and $25 \mathrm{mg} \mathrm{L}^{-}$ respectively, while the highest were 1.7 and 437 respectively. In the total, the results showed that, except for $\mathrm{Ca}$ and $\mathrm{Mg}$, the other parameters had high values in the study area.

\subsection{Fuzzy method}

The fuzzy maps prepared for the drinking water quality based on content of inorganic component parameters are shown in Fig. 6, where MF is closer to 0 with decreasing drinking water quality based on content of inorganic components, while MF is closer to 1 with increasing drinking water quality based on content of inorganic components (Soroush et al., 2013). Next, the AHP method was applied to the fuzzy parameter maps. The pair-wise comparison matrices used for preparation of the weights for each parameter in AHP are given in Table 5. The drinking water quality based on content of the inorganic components map generated using fuzzy AHP is shown in Fig. 7. 


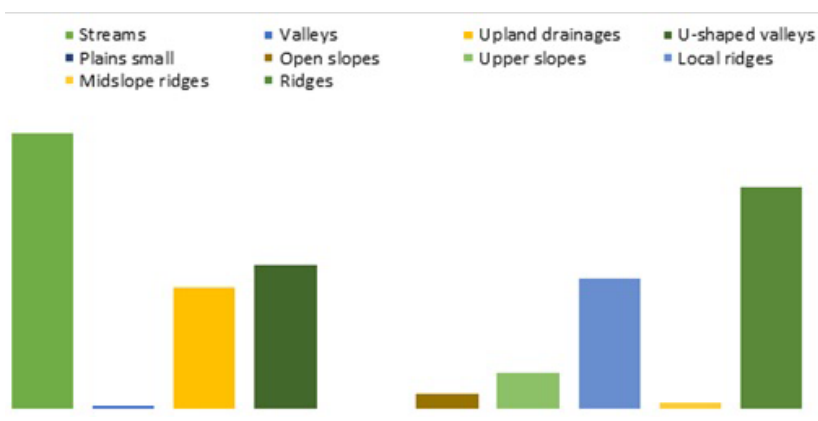

Figure 10. Areas of the landform classes.

The drinking water quality based on the content of inorganic components map is classified into four classes (Mokarram et al., 2010; Shobha et al., 2013):

- Low (not suitable for drinking): $<0.25$;

- Moderate: 0.25-0.50;

- High: 0.50-0.75;

- Very high (suitable for drinking): $>0.75$.

The results of the classification are shown in Table 6. It is found that areas with suitable drinking water quality based on content of inorganic components are located in the southeastern and south-western parts of the study area (Fig. 7).

\subsection{Landform classification}

In order to determine the relationship between landform classification and drinking water quality based on content of inorganic components, a landform classification map for the study area was prepared using TPI. The TPI maps generated using small ( 3 cells) and large (45 cells) neighbourhoods are shown in Fig. 8. TPI is between -144 to 147 and -287 to 492 for the small and large neighbourhoods respectively. The landform maps generated based on the TPI values are shown in Fig. 10. The classification has 10 classes; high ridges, midslope ridges, upland drainage, upper slopes, open slopes, plains, valleys, local ridges, midslope drainage, and streams (Fig. 9). The areas of the landform classes are shown in Fig. 10. It is observed that the largest landform is streams, while the smallest is plains.

The relationship between drinking water quality based on content of inorganic components and landform classes was determined (Fig. 11). It is found that drinking water quality based on content of inorganic components is high for streams, valleys, upland drainages, and local ridge classes, while the lowest drinking water quality based on content of inorganic components is in the plain small and midslope classes. The characteristics of landform classes, such as slope and geology, determine the drinking water quality based on content of inorganic components. For example, in the plain

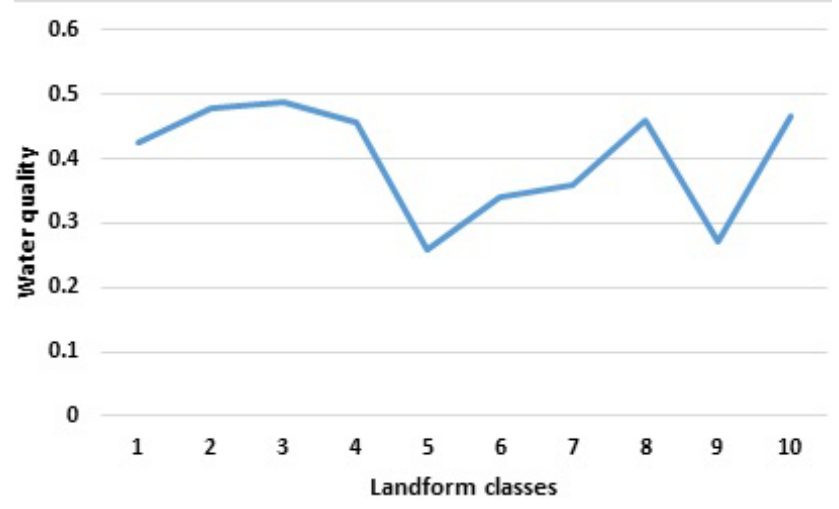

Figure 11. Relationship between drinking water quality based on content of inorganic components and landform classes.

small class, due to the low slope, there are ample opportunities for high drinking water quality based on content of inorganic components (Christiansen, 2004). Therefore, landform maps can be used to predict drinking water quality based on content of inorganic components without water sampling and analysis in the laboratory.

\section{Conclusions}

In this study, fuzzy AHP was used to study the relationship between drinking water quality based on content of inorganic components and landform classes in the south of Firozabad. It was found that $8.29 \%$ of the study area had low water quality; 64.01 , moderate; 23.33 , high; and $4.38 \%$, very high. The lands suitable for drinking water are located in the southeastern and south-western parts of the study area. The relationship between landform class and drinking water quality based on content of inorganic components shows that drinking water quality based on content of inorganic components is high in the stream, valleys, upland drainages, and local ridge classes, while the lowest drinking water quality based on content of inorganic components is in the plain small and midslope classes, so that the study determined that without measurement of water sample characteristics using a DEM and extraction landform classes by the TPI method, we can determine water quality by landform classes. For more accuracy, we suggest using a DEM with a high resolution such as radar and lidar imaging for extraction of landform classes and prediction of water quality by it.

Acknowledgements. The authors are grateful to the referees and Editor for valuable suggestions and comments which have led to the profound discussion of the results. The authors would like to thanks to all personnel of Agricultural Jihad of Fars province for their kind help.

Edited by: R. Shang

Reviewed by: S. K. Roy and one anonymous referee 


\section{References}

Aliabadi, K. and Soltanifard, H.: The Impact Of Water And Soil Electrical Conductivity And Calcium Carbonate On Wheat Crop Using A Combination Of Fuzzy Inference System And GIS, International Journal of Scientific \& Technology Research, 3, 118124, 2014.

Bijanzadeh, E. and Mokarram, M.: The use of fuzzy-AHP methods to assess fertility classes for wheat and its relationship with soil salinity: east of Shiraz, Iran: A case study, Aust. J. Crop Sci., 7, 1699-1706, 2013.

Bise, C. J.: Modern American Coal Mining: Methods and Applications, Society for Mining Metallurgy \& Exploration, ISBN: 9780873353526, 2013.

Burrough, P. A.: Fuzzy Mathematical Methods for Soil Survey and Land Suitability, J. Soil Sci., 40, 477-492, 1989.

Christiansen, D. E.: Riverbed elevations and water quality of the Missouri River at Sioux City, Iowa, 2002-03: US Geological Survey Scientific Investigations Report 2004-5079, 14 pp., 2004.

Demissie, Y., Yan, E., and Wu, M.: Assessing Regional Hydrology and Water Quality Implications of Large-Scale Biofuel Feedstock Production in the Upper Mississippi River Basin, Environ. Sci. Technol., 46.16, 9174-9182, doi:10.1021/es300769k, 2012.

Goovaerts, P.: Geostatistics in Soil Science: State-of- the-Art and Perspectives, Geoderma, 89, 1-45, 1999.

Huang, J., Zhan, J., Yan, H., Wu, F., and Deng, X.: Evaluation of the Impacts of Land Use on Water Quality: a case study in the Chaohu lake basin, The Scientific World Journal, 329187, 7 pp., 2013.

Johnston, K., Hoef, J. M. V., Krivoruchko, K., and Lucas, N.: Using ArcGISTM Geostatistical Analyst, ESRI. 380, New York, 2001.

Mahdavi, A., Niknejad, M., and Karami, O.: A fuzzy multi-criteria decision method for locating ecotourism development, Caspian J. Env. Sci., 13, 221-236, 2015.

Manoucher, A., Mini Karim, C., and Annette, J.: A comparison on a different rule based statistical models for modeling geogenic groundwater contamination, J. Environ. Model. Softw., 25, 1650-1657, 2010.
McBratney, A. B. and Odeh, I. O. A.: Application of Fuzzy sets in soil science: Fuzzy logic. Fuzzy measurements and Fuzzy decisions, Geoderma, 77, 85-113, 1997.

McBratney, A. B. and Webster, R.: Choosing Functions for Semivariograms of Soil Properties and Fitting Them to Sampling Estimates, J. Soil Sci., 37, 617-639, 1986.

Mehdi, B. B., Ludwig, R., and Lehner, B.: Determining agricultural land use scenarios in a mesoscale Bavarian watershed for modelling future water quality, Adv. Geosci., 31, 9-14, doi:10.5194/adgeo-31-9-2012, 2012.

Mokarram, M., Rangzan, K., Moezzi, A., and Baninemehc, J.: Land suitability evaluation for wheat cultivation by fuzzy theory approache as compared with parametric method. The international archives of the photogrametry, Remote Sens. Spatial Information Sci., 38, 1440-145, 2010.

Oliver, M. A.: Kriging: A Method of Interpolation for Geographical Information Systems, International Journal of Geographic Information Systems 4, 313-332, 1990.

Sharifi-Rad, J., Hoseini-Alfatemi, S. M., Sharifi-Rad, M., and Setzer, W. N.: Chemical composition, antifungal and antibacterialActivities of essential oil from lallemantia Royleana (benth. In wall.) Benth, J. Food Safety, 35 19-25, 2014.

Shobha, G., Gubbi, J., Raghavan, K. S., Kaushik, K., and Palaniswami, M.: A novel fuzzy rule based system for assessment of ground water potability: A case study in South India, IOSR Journal of Computer Engineering (IOSR-JCE), 15, 35-41, 2013.

Soroush, F., Mousavi, S. F., and Gharechahi, A.: A fuzzy industrial water quality index: case study of zayandehrud river system, IJST, Transactions of Civil and Environmental Engineering, 35, 131-136, 2013.

Weiss, A.: Topographic Position and landforms Analysis, Poster presentation, ESRI user Conference, San Diego, C.A., 2006.

William, L. J. and Randall, P. J.: Runoff and water quality from three soil landform units on mancos shale, J. Am. Water Resour Assoc., 18, 995-1001, 2007.

Zadeh, L. H.: Fuzzy sets, Information and Control, 8, 338-353, 1965. 